\title{
The Impact of Job Satisfaction on Organizational Citizenship Behavior: A Review of Literature
}

\author{
Hemakumara, M.G.G, Ph.D. \\ Senior Lecturer, Institute of Human Resource Advancement \\ University of Colombo \\ Sri Lanka
}

\begin{abstract}
Employee job satisfaction is the balance between employees expectation from the organization and the rewards, both financial and non-financial, that an organization provides to employees. Organizational citizenship behavior is the extra contribution of the employee to the organization which is beyond the required work level as expected by the organization. This research paper aims to explore the effect of job satisfaction on organizational citizenship based on the literature review of selected research articles. It had been previously found that job satisfaction had a positive significant relationship with the organization citizenship behavior of employees in various other sectors and industries. The findings of this study confirmed that there is a significant and positive relationship exists between job satisfaction and organizational citizenship behavior of employees in different industries. Therefore it is recommended maintaining accepted level of job satisfaction among employees to enhance the organizational citizenship behavior.
\end{abstract}

Key word: Employees job satisfaction, organization, organizational citizenship behavior.

\section{Introduction}

Job satisfaction is considered as an essential requirement for organizations that help to achieve objectives of their organization. .Job satisfaction includes the favourable attributes and good feelings which employees have on their work. By extension, job satisfaction means meaningful and favourable attitudes towards individual's job whilst an unfavourable attitude indicates the job dissatisfaction. Only satisfied employees will engage in the effective functioning of the organization (Chiboiwa, 2011).

At the same time Organizational Citizenship Behavior (OCB) is a comparatively new concept in the field of Human Resource Management and Organizational Behaviuor, which it has become a fertile research area today. It is revealed that the OCB make encourage the extra job be behaviour of employees which is impartial for an organization to be effective (Cazares 2011).

The main purpose of this study is to find the impact of job satisfaction with OCB. The current study therefore attempts to review the existing literature by examining selected researches conducted in different countries.

\section{Job Satisfaction}

Researchers and academics and have emphasized on the employee job satisfaction ,because of its direct relationship with the other concepts such as motivation, performance, alienation, exhaustion, leave of employment and OCB (Gunay,2018). Jawabri (2017) has defined the job satisfaction as the feeling of contentment that an employee derive from his or her duty and responsibilities in the workplace. Saeed et al (2013) defined job satisfaction as an emotional state of happiness. It is about how employees obliged to attend the work and how they are compelled to perform duty and their expectations from the job.

Givaki et al (2017) show that the job satisfaction is one of the most crucial and perhaps most controversial concept in organizational behaviour and human resource management.

Further, job satisfaction focused on the fundamental and theoretical effort.on the other hand job satisfaction has become avery important for all levels of employees and managers. Therefore job satisfaction is essential to the success of any organization. The job an individual does has to be satisfied enough to keep them perpetual happy. Also Job satisfaction expresses the extent in between reward that the job provides and employees expectations from the organization.(Adenuga 2015).

\section{Organizational Citizenship Behaviour}

OCB is relatively modern management concept that has originated nearly three decades ago. Many researchers have explored that OCB has an essential impact on organizations effectiveness in increasing employee morale and fulfilling organizations set objectives (Demirel et al 2018) 
Mohamed (2016) defined OCB as an individual behavior which could motivate employees to go beyond the expected work level by the organization and their job description. This behavior benefits both employees and individual. Zeyda (2018) has explained that OCB is optional and voluntary behavior that an individual would play. However these behaviours are not aiming to satisfy or fulfill employees own personal benefit but to encourage engagement in the organization. However, OCB is of great importance to both the organization and the employee, such as improve organizational performance, building reciprocal relations employees among different departments, improve unity and cohesion of the organization and reduce the level of the need of scare resources.

Unal (2013) has explored the five dimensions of OCB as altruism, conscientiousness, sportsmanship, courtesy and civic virtue. Altruism is the helpfulness or helping behavior. Conscientiousness is a discretionary behavior which goes even beyond the minimum duty requirement of the organization. This includes obeying rules and regulations, not taking extra break and working extra-long hours. Sportsmanship is the willingness of tolerating personal inconveniences and doing duty without complains protests, accusations or grievances. Courtesy is preventing of creating problems among co- workers and reduce intergroup conflicts. Civic virtue is the employees concern or involvement about life of the organization, monitor organizations opportunities and treats, look for the best interest of the organization and the willingness of active participation for organizations events

\section{The Impact of Job Satisfaction on Organizational Citizenship Behaviour}

A number of researchers have explained the relationship between job satisfaction and OCB. Mohammad (2016) has found the relationship between job satisfaction and OCB among non-academic staff of Malaysian University System and found that both intrinsic job satisfaction and extrinsic job hve a positive effect on OCB. Unal (2013) revealed that the relationship between four factors of job satisfaction (company policies, supervision and promotion, job itself, pay and fellow workers) and four dimensions of OCB. (Altruism, courtesy, sportsmanship, civic virtue). It was found that different factors of job satisfaction have various impacts on different dimensions of OCB. In Sammy, the researcher has pointed that company policies, supervision and promotion have a positive effect on altruism, civic virtue and courtesy.. Fellow workers have a positive effect on altruism, civic virtue while pay has a positive effect on courtesy. In another study Basirudin et al (2016) have developed a conceptual model to explain the relationship between job satisfaction and OCB. In this model five factors of job satisfaction (pay, promotion, co-workers, supervision and work itself) have been taken as independent variables where five dimensions OCB (altruism, sportsmanship, courts, conscientiousness and civic-virtue) have been taken as dependent variable.

There is a significant relationship between job satisfaction and OCB of financial Sector employees in Turkey,(Gunay, 2018).

Pay attention for OCB and job satisfaction is of important in increasing employee work quality and performance. It is more important when there exists a job pressure. The OCB study conducted based on Health Employees of universities, revealed that there is a positive relation between job satisfaction and OCB. (Fadiallah 2015)

Researches have contributed to the direction of job satisfaction affect the OCB. The Table 1.Summaries these findings.

Table 1: Studies Show the Relationship Between Job Satisfactions and Organizational Citizenship Behaviour

\begin{tabular}{|c|c|c|c|}
\hline Study & Population & Methodology & Result \\
\hline $\begin{array}{l}\text { Maio\& Kim } \\
(2010)\end{array}$ & $\begin{array}{l}\text { Steel Coperations in } \\
\text { China } \\
\mathrm{N}=159\end{array}$ & Survey & $\begin{array}{l}\text { More job satisfaction promote more OCB but more job } \\
\text { satisfaction cannot promote more job performance } \\
\text { relatively. }\end{array}$ \\
\hline $\begin{array}{l}\text { Arif\&Chohan } \\
\text { (2012) }\end{array}$ & $\begin{array}{l}\text { Bank employees in } \\
\text { Pakistan } \\
\mathrm{N}=350\end{array}$ & Survey & $\begin{array}{l}\text { Direct and positive relationship between job satisfaction } \\
\text { and OCB }\end{array}$ \\
\hline Unal (2013) & $\begin{array}{l}\text { Employees of group of } \\
\text { companies in Pakistan } \\
\mathrm{N}=199\end{array}$ & Survey & $\begin{array}{l}\text { There is a positive significant relationship between job } \\
\text { satisfaction with OCB. }\end{array}$ \\
\hline $\begin{array}{l}\text { Pavalachellie } \\
\text { (2013) }\end{array}$ & $\begin{array}{l}\text { Army employees and } \\
\text { public sector and private } \\
\text { sector employees in } \\
\text { Romania } \\
\mathrm{N}=118\end{array}$ & Survey & $\begin{array}{l}\text { Employees those satisfied with their work tend to more } \\
\text { frequently adept OCB. Those who have higher education } \\
\text { get more involved in OCB. }\end{array}$ \\
\hline $\begin{array}{l}\text { Mohamed } \\
(2016)\end{array}$ & $\begin{array}{l}\text { Cement company } \\
\text { employees in Egypt } \\
\mathrm{N}=325\end{array}$ & Survey & $\begin{array}{l}\text { Both intrinsic and extremism job satisfaction affect } \\
\text { positively on OCB. }\end{array}$ \\
\hline Demirel et al (2018) & $\begin{array}{l}\text { Past research Conducted } \\
\mathrm{N}=67\end{array}$ & $\begin{array}{l}\text { Analytical } \\
\text { descriptive } \\
\text { approach }\end{array}$ & $\begin{array}{l}\text { Confirmed the positive relationship between job } \\
\text { satisfaction and OCB. }\end{array}$ \\
\hline
\end{tabular}

Source: Developed for this research 


\section{Conclusion}

Job satisfaction is crucial for determining the organization citizenship behavior (OCB) among employees. Employees, those having high level of OCB will contribute organization to achieve its objectives and further contributes to organization effectiveness and performance (Organ 2018). Therefore job satisfaction is important not only to satisfy employees, but also to improve OCB..In previous studies (Organ 2018; Unal 2013, Pavalachellie 2013, Arif \& Chohan 2012; Maio\& Kim 2010) have revealed that the strong relationship between job satisfaction and OCB. Further these studies have explored that the highly satisfied employees show high OCB than others. Thus OCB leads to delivering better organizational output and retained customers. In addition to that, OCB reduces employee turnover, enhance organizational commitment, and economized on organizational resources.

\section{References}

Adenuga, O. A. (2015). Impact of Occupational Stress on Job Satisfaction and Mental Health of First Bank Employees: Implication for Personnel Psychologists. Science, 1(1), 15-21.

Aliyu, A. A., Bello, M. U., Kasim, R., \& Martin, D. Positivist and Non-Positivist Paradigm in Social Science Research: Conflicting Paradigms or Perfect Partners? Journal of Management and Sustainability, 4(3), 79.

Arif, A., \&Chohan, A. (2012). How job Satisfaction is influencing the organizational citizenship behavior (OCB): A study on employees working in banking sector of Pakistan. Interdisciplinary Journal of Contemporary Research in Business, 4(8), 74-88.

Chiboiwa ,M. E. , CrispenChipunza and Michael O. Samuel (2011).Evaluation of job satisfaction and Organisational citizenship behaviour: Case study of selected organisations in Zimbabw African Journal of Business Management Vol. 5(7), pp. 2910-2918, 4 April, 2011

Demirel, Y., Elhusadi, I., \&Alhasadi, A. (2018).The Relationship between Organizational Citizenship Behavior and Organizational Factors.International Journal of Business and Management Invention (IJBMI), 7(3), 27-39.

Fadlallh, A. W. A. (2015). Impact of Job Satisfaction on Employees Performance an Application on Faculty of Science and Humanity Studies University of Salman Bin Abdul-Aziz-Al Aflaj.International Journal of Innovation and Research in Educational Sciences, 2(1), 26-32.

Givaki, E., Davoudi, H., Manzari, A. R., \&AlipourKatigarie, S. (2018). Job Satisfaction Prediction based on Job Motivation and Emotional Intelligence of Managers and Employees. Iranian journal of educational sociology, 1(7), 112-118.

Günay, G. Y. (2018). Relationship between Job Satisfaction, Organizational Citizenship Behavior and Employee Performance: Sample of Edirne Financial Office Employees in Turkey. American International Journal of Contemporary Research, 8, 64-74.

Jawabri, A. (2017). Job Satisfaction of Academic Staff in the Higher Education: Evidence from Private Universities in UAE. International Journal of Human Resource Studies, 7(4), 193-211.

Kivistö, J., \&Pekkola, E (2017). Quality of Administration

Miao, R., \& Kim, H.-G. (2010). Perceived organizational support, job satisfaction and employee performance: An Chinese empirical study. Journal of Service Science and Management, 3(02), 257.

Mohamed, W. S. E. D. (2016). Investigating the Relationship between Job Satisfaction and Organizational Citizenship BehaviorAmongBeniSuef Cement Company Employees. 6(5), 2-7.

Organ, D. W. (2018). Organizational Citizenship Behavior: Recent Trends and Developments. Annual Review of Organizational Psychology and Organizational Behavior, 80, 295-306

.Pavalache-Ilie, M. (2014). Organizational citizenship behaviour, work satisfaction and employees' personality. Procedia-Social and Behavioral Sciences, 127, 489-493.

Saeed, R., Mussawar, S., Lodhi, R. N., Iqbal, A., Nayab, H. H., \&Yaseen, S. (2013). Factors affecting the performance of employees at work place in the banking sector of pakistan. Middle-East Journal of Scientific Research, 17(9), 1200-1208.

Ünal, A. P. Ö. F. (2013). Relationship between the facets of job satisfaction and the dimensions of organizational citizenship behavior: Mediating role of organizational commitment. SüleymanDemirelÜniversitesilktisadiveİdariBilimlerFakültesiDergisi, 18(1).

Zeyada, M. (2018).Organizational Culture and its Impact on Organizational Citizenship Behavior.International Journal of Academic Research in Business and Social Sciences, 8(3), 418-429. 